\title{
Physical dispersion of radioactive mine waste at the rehabilitated Radium Hill uranium mine site, South Australia
}

\author{
B. G. LOTTERMOSER ${ }^{1 *}$ AND P. M. ASHLEY ${ }^{2}$
}

${ }^{1}$ School of Earth Sciences, James Cook University, PO Box 6811, Cairns, Q/d 4870, Australia.

${ }^{2}$ Earth Sciences, University of New England, Armidale, NSW 2351, Australia.

\begin{abstract}
The Radium Hill uranium deposit, in semiarid eastern South Australia, was discovered in 1906 and mined for radium between 1906 and 1931 and for uranium between 1954 and 1961 (production of 969300 t of davidite ore averaging $0.12 \% \mathrm{U}_{3} \mathrm{O}_{8}$ ). Rehabilitation was limited to removal of mine facilities, sealing of underground workings and capping of selected waste repositories. In 2002, gamma-ray data and samples of tailings, uncrushed and crushed waste rock, stream sediment, topsoil and vegetation were collected to assist in examining the current environmental status of the mine site. The data indicate that capping of tailings storage facilities did not ensure the long-term containment of the low-level radioactive wastes due to the erosion of sides of the impoundments. Moreover, wind erosion of waste fines (phyllosilicates, ore minerals) from various, physically unstable waste repositories has caused increasing radiochemical (from a background dose of $35-70 \mathrm{nSv} / \mathrm{h}$ to max. $0.94 \mu \mathrm{Sv} / \mathrm{h}$ ) and geochemical (Ce, Cr, La, Lu, Rb, Sc, Th, U, V, Y, Yb) impacts on local soils. Plants (saltbush, pepper tree) growing on waste dumps display evidence of biological uptake of lithophile elements, with values being up to 1-2 orders of magnitude above values for plants of the same species at background sites. However, radiation doses associated with the mine and processing site average $0.67 \mu \mathrm{Sv} / \mathrm{h}$; hence, visitors to the Radium Hill site will not be exposed to excessive radiation levels. Although rehabilitation procedures have been partly successful in reducing dispersion of $U$ and related elements into the surrounding environment, it is apparent that 20 years after rehabilitation, there is significant physical and limited chemical mobility, including transfer into plants. Additional capping and landform design of the crushed waste and tailings repositories are required in order to minimise erosion and impacts on surrounding soils and sediments.
\end{abstract}

KEY WORDS: contaminants, erosion, Radium Hill, South Australia, tailings, uranium.

\section{INTRODUCTION}

Mining, mineral processing and metallurgical extraction of uranium ores result in the production of tailings, waste rocks, and heap-leach residues. Potential environmental impacts of uranium mine wastes prior to, during and after mining include: excessive radioactivity levels and radon emissions; inappropriate use of tailings and waste rocks; failure of tailings storage facilities; soil, sediment, and ground and surface water contamination; and acid mine drainage (Lottermoser 2003). Hence, uranium mine sites and in particular their waste repositories require appropriate remediation measures. Recent research on rehabilitated uranium mine sites located in wet climates has revealed the varied success of the applied rehabilitation efforts (Menzies \& Mulligan 2000; Peacey et al. 2002; Ritchie \& Bennett 2003). In wet and seasonally wet climates, acid mine drainage development and the leaching of waste repositories are dominant pathways of contaminants into surrounding environments. In fact, a number of studies on Australia's uranium mine sites located in wet climates (e.g. Rum Jungle) have highlighted the importance of leaching processes and chemical mobility of contaminants (Richards et al. 1996; Taylor et al. 2003). In comparison, there is little knowledge of the status and environmental impacts of rehabilitated uranium mines in dry climates. To date, the few studies conducted on rehabilitated uranium mine sites in semiarid and arid climates have largely focused on uranium mill tailings repositories and related ground and surface water investigations (Abdelouas et al. 1998; Lottermoser \& Ashley 2005).

In this paper, we investigate the transfer of radioactive material from waste rock dumps and tailings storage facilities into soils, sediments and plants at the rehabilitated Radium Hill uranium mine that is located in semiarid South Australia. The study was undertaken to determine: (i) the radiometric, mineralogical and geochemical characteristics of uraniferous waste rock dumps and tailings repositories; (ii) the geochemical properties of soils and sediments impacted by the waste

\footnotetext{
*Corresponding author: bernd.lottermoser@jcu.edu.au
} 
repositories; and (iii) the performance of the rehabilitation measures applied to the waste repositories. Hence, this case study contributes to improved rehabilitation of waste repositories of uranium mine sites in semiarid climates.

\section{RADIUM HILL AREA}

\section{Physiography, climate and vegetation}

The abandoned uranium mine and town site of Radium Hill is located $440 \mathrm{~km}$ north-northeast of Adelaide, South Australia $\left(32^{\circ} 21^{\prime} \mathrm{S}, 140^{\circ} 38^{\prime} \mathrm{E}\right)$ (Figures 1,2$)$. The site is located in gently undulating topography with altitudes reaching $270 \mathrm{~m}$ and an average elevation of $220 \mathrm{~m}$ above sea level. Radium Hill has a semiarid climate. Average annual winds are predominantly blowing from the south, north and west (Broken Hill weather station, $100 \mathrm{~km}$ to the northwest: Bureau of Meteorology 2005). The average annual rainfall is $200 \mathrm{~mm}$. Average temperatures range from $3^{\circ} \mathrm{C}$ in winter to $33^{\circ} \mathrm{C}$ in summer (Forbes 1991). Consequently, vegetation is relatively sparse, with saltbush and bluebush species, native grasses and small trees (mulga, black oak, false sandalwood). Larger trees such as river red gums occur along some of the major ephemeral streams. The main land use in the district is low-density grazing.

Soils in the area are commonly skeletal loams on the hills, but thicken into red duplex and calcareous soils on

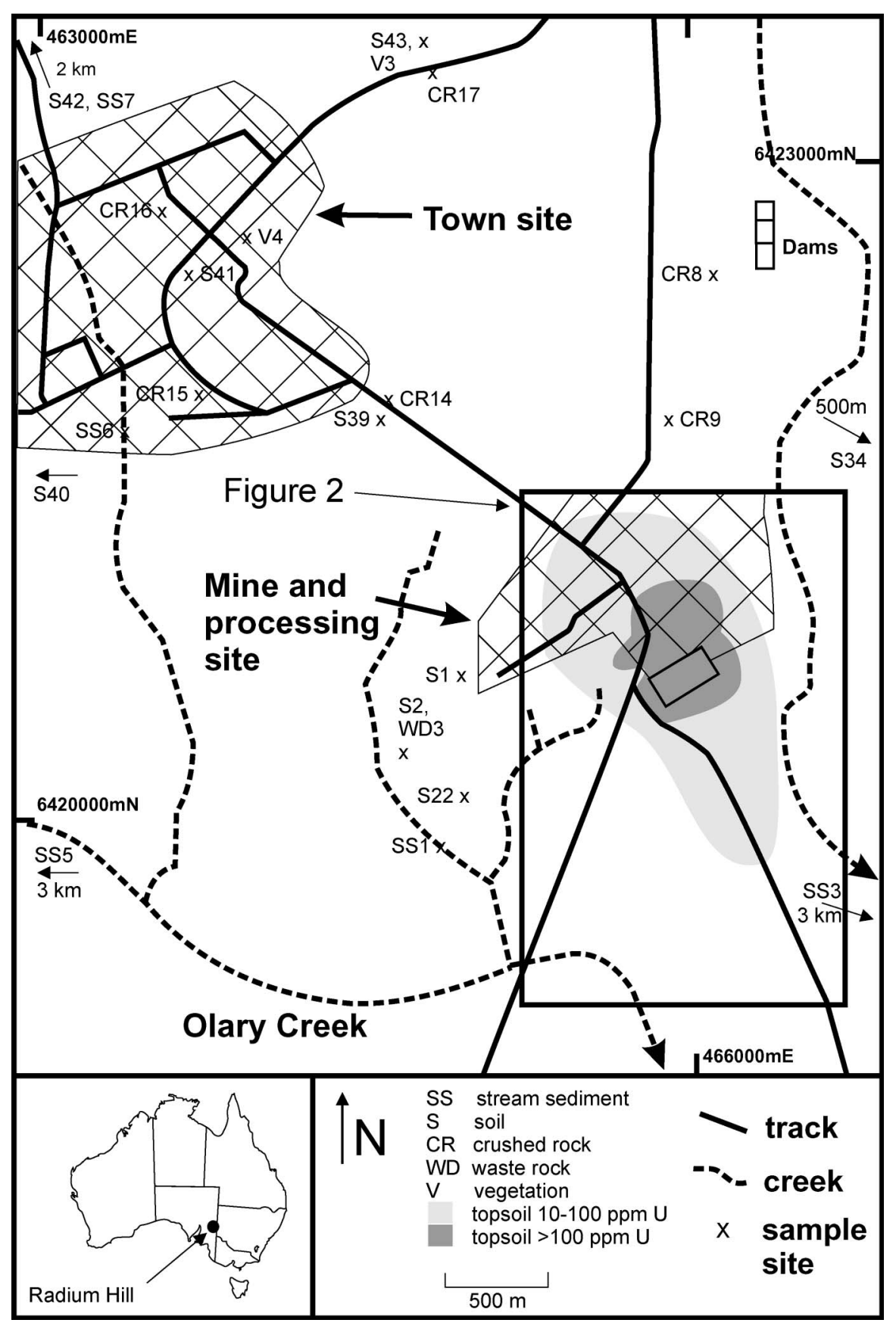

Figure 1 Plan of the Radium Hill town site and mine and processing area. Locations of various sample media are indicated. The uranium distribution in topsoils of the mine and processing site is also indicated. Highly contaminated soils (>100 ppm U) are associated with the main tailings storage facility. 
Figure 2 Detailed plan of the Radium Hill mine and processing site showing the location of the main tailings storage facility and waste rock dumps. Locations of ground radiometric survey transects and various sample media are also indicated.

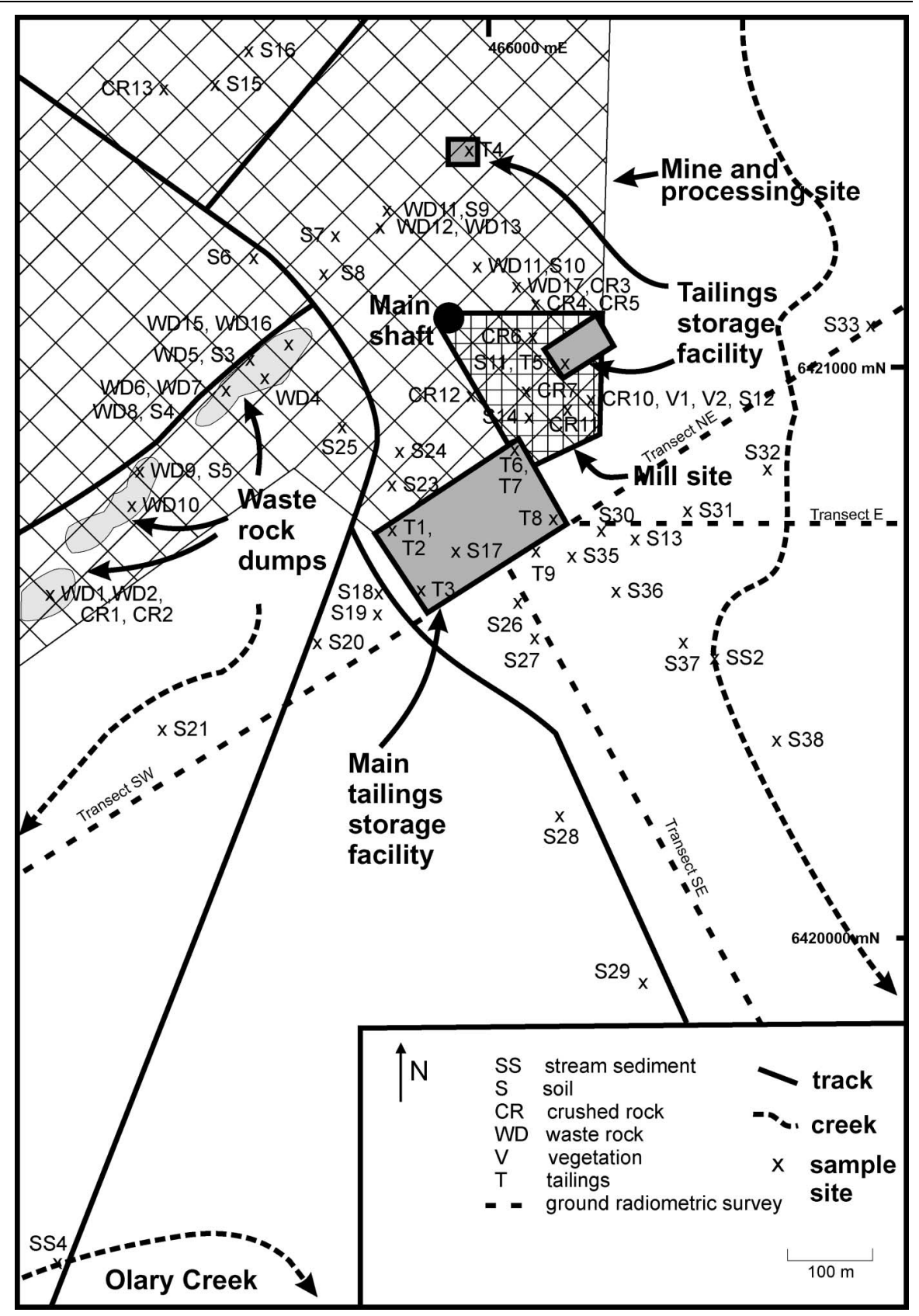

plains. Calcrete development is common in all nonalluvial soils. Rock outcrop is moderate in the hill regions, but sparse to absent elsewhere. Finer soil material may be partly wind-deposited and, in the vicinity of the mine site, can include a minor to significant proportion of windborne and waterborne mine tailings and other detritus.

Drainage from the Radium Hill mine and town area is via two approximately south-flowing ephemeral creeks (and their tributaries) into the major watercourse of the district, Olary Creek (Figure 1). The streams are locally entrenched up to $3 \mathrm{~m}$ into Holocene and Late Tertiary windblown silt and sand, and fluvial sands and gravels. It is only after heavy rain events that there is surface water flow, although it is evident that these events are the major cause of erosion and sediment transport in the region.

\section{Geology}

Uranium mineralisation at Radium Hill is hosted in high-grade metamorphic rocks of the Willyama Supergroup in the Olary Domain. These are of Palaeoproterozoic age ( $c a 1700 \mathrm{Ma}$ ) and include metasedimentary quartzo-feldspathic gneiss, composite gneiss, quartz-feldspar-biotite schist and amphibolite. It is likely that these rocks are part of the Wiperaminga Subgroup of Conor (2000) and correlate with the lower part of the Willyama Supergroup sequence in the Broken Hill region, $50-100 \mathrm{~km}$ to the northeast.

The host-rocks for mineralisation have been folded into a dome-like structure. Several subparallel vein-like orebodies (lodes) occupy northeast-striking shear zones cutting drag folds on the overturned western limb of the dome (Blissett 1975). The lode systems were traced 
continuously for $1400 \mathrm{~m}$ along strike and typically dipped to the southeast at $30-70^{\circ}$ (Parkin \& Glasson 1954). The lodes occupied shear structures containing abundant biotite and quartz, with patchy to nodular aggregates of oxide minerals. The latter form complex intergrowths and include ilmenite, rutile, magnetite, hematite and davidite. Parkin and Glasson (1954) noted that lode development was commonly wider and of better grade where lodes intersected amphibolite. In such zones, strong biotite (-oxide mineral) alteration is commonly evident. Lode zones were also associated with lode-parallel and cross-cutting pegmatite and aplite masses, and were cut by later amphibolites. Surface oxidation effects are relatively minor as the oxide material forming the ore was refractory; minor carnotite occurs as a replacement of davidite, and oxide minerals are mainly physically dispersed into the regolith materials.

\section{History of mining}

Uranium was discovered at the site of Radium Hill in 1906, and the new UTiFe mineral davidite was reported from the location by Mawson (1906) and Whittle (1959). Mining occurred intermittently for radium between 1906 and 1931, and owing to the need to locate uranium for the then incipient atomic age, an exploration program commenced in 1944, leading to the development of an underground mine, with uranium production starting in 1954 (Parkin \& Glasson 1954). Mining occurred to a depth of $290 \mathrm{~m}$ and along a maximum strike length of $915 \mathrm{~m}$ in a series of vein-like lode systems averaging $1 \mathrm{~m}$ in width but up to $7.5 \mathrm{~m}$ wide (Blissett 1975). Although mineralisation was intersected in drillholes to a depth of $450 \mathrm{~m}$, reserves of easily accessible ore at depth were negligible. Mining continued until 1961, with production of $969300 \mathrm{t}$ of davidite ore, averaging $0.12 \% \mathrm{U}_{3} \mathrm{O}_{8}$. This was beneficiated on site to a concentrate that was subsequently railed for treatment at Port Pirie to produce $852 \mathrm{t} \mathrm{U}_{3} \mathrm{O}_{8}$, plus byproduct rare earths and scandium oxide (Parkin 1965; Blissett 1975; McKay \& Miezitis 2001).

Leading up to the start of mining in 1954, a substantial town and industrial site was constructed, with the town eventually having a population of about 1000. The town was located about $3 \mathrm{~km}$ west-northwest of the mine/industrial site (Figure 1).

\section{Rehabilitation}

Following closure of the mine, most buildings were transported away or demolished, leaving only foundations. However, a few of the larger concrete structures remain (Figure 3a). Waste rock and mill tailings dumps were simply left uncovered (Figure $3 \mathrm{~b}$ ). Owing to the semiarid climate and propensity for windy conditions (particularly from the northwest to southwest quadrants), the finer mill tailings material was subject to wind deflation, leading to spreading of winddeposited tailings about the main tailings storage facility. As a result of this condition, capping of mill tailings material with a soil layer was instigated in the early 1980s.

\section{SITE DESCRIPTION}

\section{Mine/industrial area}

The Radium Hill mine site and associated processing area and workshops, etc., cover an area of $\sim 1 \mathrm{~km}^{2}$. The site encompasses numerous relicts and foundations of buildings and other structures, although the only substantial remains are those of the main orepass and crusher, plus two large concrete ore bins, adjacent to the former main shaft and mill site (Figure 3a). Several roads serviced the area, as well as a rail siding near the mill. Numerous waste dumps of uncrushed rock occur adjacent to former shafts over a strike length of $\sim 800 \mathrm{~m}$ along the trace of the line of lode. These are up to $5 \mathrm{~m}$ thick and cover individual areas of up to $10000 \mathrm{~m}^{2}$ (Figure 2). Adjacent to the mill site are several dumps of finely crushed rock (commonly $<2 \mathrm{~cm}$ grainsize), some individually containing up to $\sim 40000 \mathrm{t}$, as well as smaller dumps of more coarsely crushed waste rock (Figure 3b).

There are at least three dumps (dams) in which fine mill tailings have been stored (Figure 2) that have subsequently been largely covered by soil and weathered rock excavated from trenches alongside each dump (Figure 3c). A couple of other sites have also been soilcovered, but what lay underneath was not ascertained. A small tailings dam about $250 \mathrm{~m}$ north of the main shaft may relate to an earlier phase of mining (sample $\mathrm{T} 4$, Figure 2). The other identified tailings dams are to the south and southeast of the main shaft, with a smaller dam adjacent to the mill site (sample T5, Figure 2) and the larger main tailings storage facility a few hundred metres to the south (Figure 2).

The larger tailings storage facility, hereafter called the main tailings storage facility, has dimensions of approximately $250 \times 150 \mathrm{~m}$, is at least $5-6 \mathrm{~m}$ thick and has slopes of $20-25^{\circ}$ (Figures 2, 3c). It is one of the main foci of this study due to its size and the fact that it was subject to considerable wind and water erosion prior to being capped. The capping material on the main tailings storage facility is $\sim 1 \mathrm{~m}$ thick and composed of relatively consolidated soil, with minor weathered rock and calcrete. The surface is now partly vegetated by saltbush and acacia species, although the steep sides are relatively bare and have been subject to local water erosion, thus exposing bedded fine tailings in places (Figure 3c). At one corner of the small tailings dam near the mill site, erosion of the cover has again exposed bedded tailings (Figure 3d).

Wind and water dispersion of tailings and crushed rock dumps has occurred and remains active at uncovered sites. Prior to covering, wind deflation was evidently significant about the main tailings storage facility, and fine tailings material has been dispersed in all directions (Figure 4). Windblown tailings material, up to tens of centimetres thick, is particularly common up to $80 \mathrm{~m}$ away on the northeast and southeast sides of the main tailings storage facility. Small amounts of windblown tailings remain evident for at least $500 \mathrm{~m}$ distant on the southeast side of the main tailings storage facility. The dispersion to the northeast and southeast reflects the direction of the prevailing strong winds to 

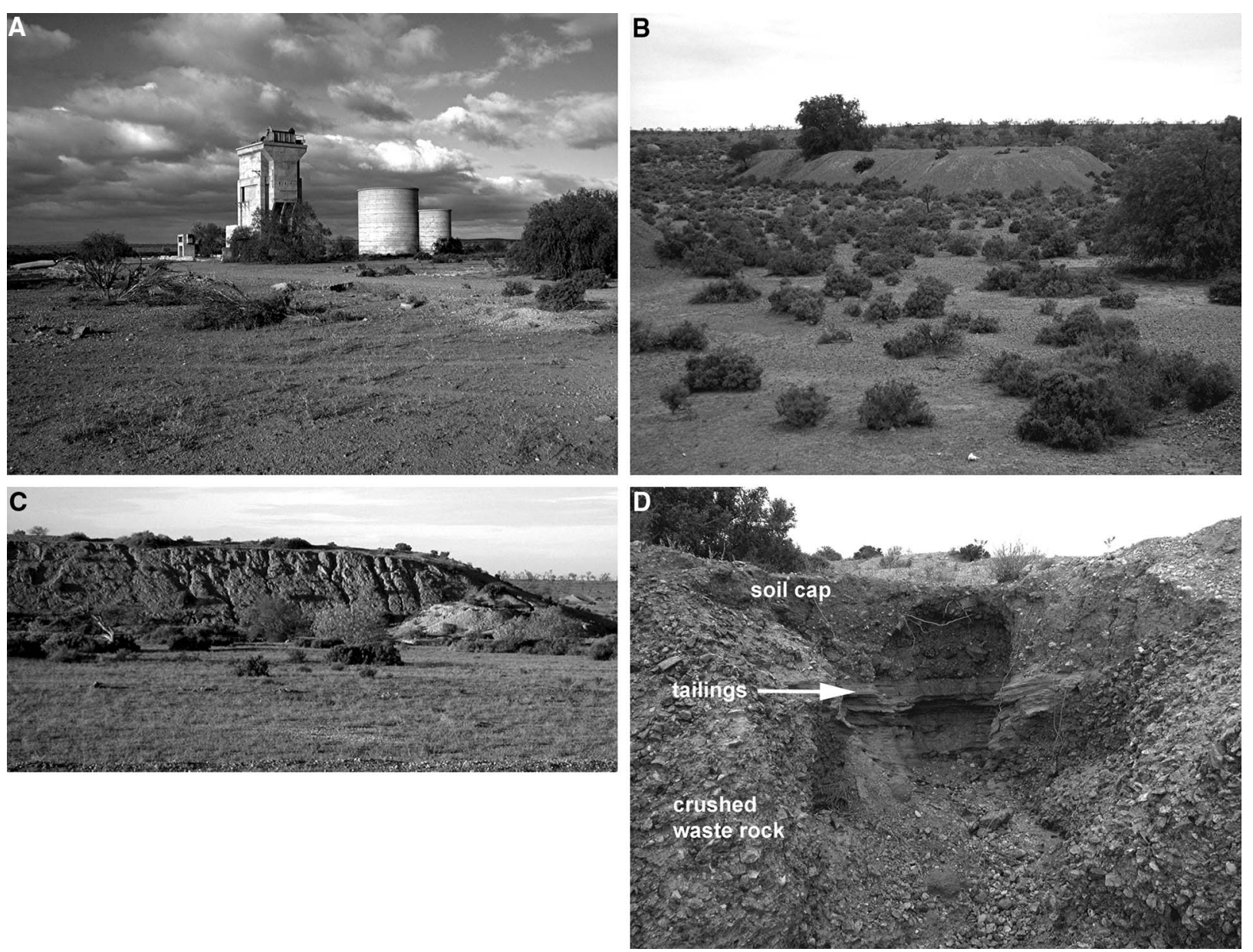

Figure 3 (a) Remnant crusher and ore bins adjacent to the former main shaft and mill site (near main shaft, Figure 2). Residual strongly mineralised material is scattered about the structures. (b) Dump containing finely crushed waste rock material (427 ppm U, $0.48 \mu \mathrm{Sv} / \mathrm{h}$ ) (near CR10, Figure 2). There has been significant physical dispersion of this material by water and wind. Plants growing on this material (saltbush, foreground; pepper tree, background) demonstrate uptake of U and related trace elements, relative to a background site. (c) Rill erosion of the soil-capped main tailings storage facility, northwest corner (height of facility approximately $6 \mathrm{~m}$ ) (near T1, T2, Figure 2). The soil capping is being removed, resulting in the exposure of tailings in rills. (d) Erosion and incision of a covered mill tailings dam (near S11, T5, Figure 2). The tailings $(3.5 \mu \mathrm{Sv} / \mathrm{h}, 5500 \mathrm{cps}, 1600 \mathrm{ppm} \mathrm{U})$ were originally (1950s-1960s) placed in a depression of crushed waste rock and then capped with soil containing calcrete and rock fragments. The soil cover reduces the radiation levels to $0.1 \mu \mathrm{Sv} / \mathrm{h}$, as measured at the cover's surface.

the north, south and east (Bureau of Meteorology 2005), although east of the main tailings storage facility, the dispersion plume has probably been largely removed by subsequent flooding of a wide stream channel. Uncovered dumps of finely crushed rock remain susceptible to wind and water erosion and it is evident that major rainfall events have caused movement of even coarsely crushed waste rock for hundreds of metres (Figure $3 b$ ).

\section{Town, roads and railway}

Throughout the mine/industrial site, finely to coarsely crushed rock from the mine has been used for ground cover at worksites, roads (including as a component of asphalt) and concrete structures. The asphalt road linking the town to the mine used finely crushed material and many other roads leading away from the town and mine used coarsely crushed material for surfacing. Coarsely crushed waste rock was used as railway ballast along the length of the $18 \mathrm{~km}$ spur line from Radium Hill to the main Broken Hill-Port Pirie railway and was also used on the latter route prior to the standard-gauge railway being opened in 1969 .

\section{MATERIALS AND METHODS}

\section{Ground radiometric survey}

A ground radiometric survey of the waste rock dumps, tailings repositories and adjacent soils was conducted in the form of a series of transects and loops using a portable Exploranium GR-320 spectrometer with a 512 channel spectrometer and a $350 \mathrm{~cm}^{3}$ sodium iodide detector. Radiometric data were continuously recorded for $60 \mathrm{~s}$ during the survey and acquired at a speed of 


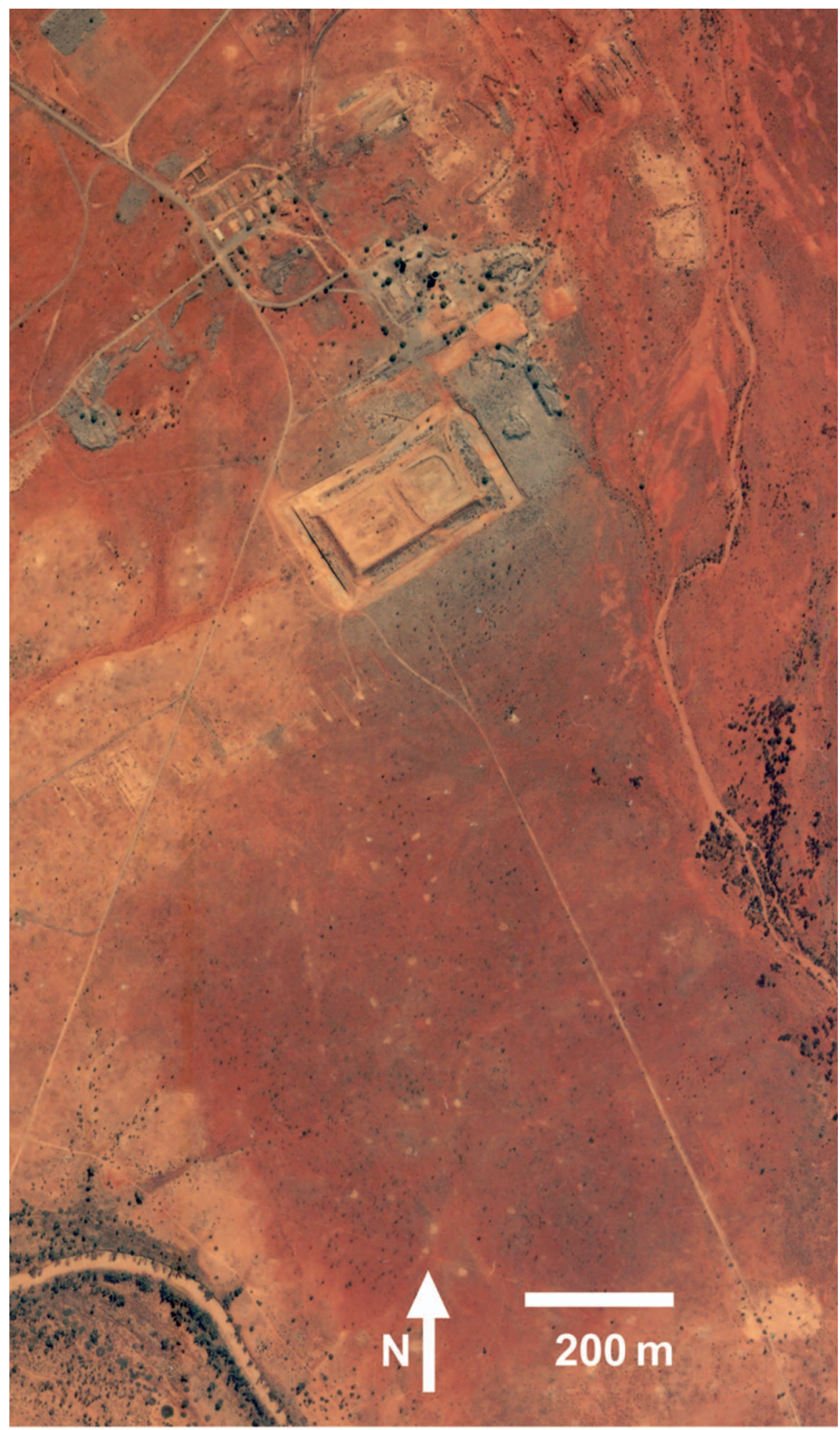

Figure 4 Aerial photograph of the Radium Hill mine and processing site (courtesy of Mapland, Environmental Information, Department for Environment and Heritage South Australia). Uncovered material has a grey colour with a blue tint, whereas soil coverings are pale orange-brown. The windborne dispersion plume of fine tailings about the main tailings storage facility (large rectangular structure) is evident for several hundred metres distance (except to the southwest), giving a pale grey-blue colouration to the soil.

$\sim 1 \mathrm{~m} / \mathrm{s}$. Measurements are confined to the upper $0.3 \mathrm{~m}$ of the soil/rock and were taken at a detector elevation of $\sim 1 \mathrm{~m}$ above dry ground. This survey design ensured that the gamma-ray data represent large soil/rock units of several metres in lateral dimension. Units of radiation exposure $(\mu \mathrm{R} / \mathrm{h}, \mathrm{nSv} / \mathrm{h})$ and radionuclide abundance (wt $\% \mathrm{~K}, \mathrm{ppm} \mathrm{U}, \mathrm{ppm} \mathrm{Th}$ ) were recorded. In addition, a Scintrex BGS-1SL scintillometer was used to count the local gamma-ray activity by means of traverses and loops and at each sample site in counts per second (cps).

\section{Sampling and sample preparation}

Fieldwork was conducted in June 2002, with collection of several different sample media [waste rock dumps; crushed rock (including road gravel and railway ballast); tailings; soils; stream sediments; vegetation]. 
All non-vegetation samples were representative composites, and each constituted several kilograms. Soil samples were topsoil materials, from depths of $0-10 \mathrm{~cm}$. They were taken from the town and mine area and surrounding district. Outlying soil samples were taken at distances up to $8 \mathrm{~km}$ from the mine area in order to obtain representative background element values. Stream sediment samples (active material) were collected from: (i) uncontaminated Olary Creek upstream and west of the Radium Hill site (local background); and (ii) local streams draining the site.

All samples were air-dried. Stream sediment and soil samples were dry-sieved to $<180 \mu \mathrm{m}$. Consistent with common geochemical stream-sediment surveys (Van Loon \& Barefoot 1989), the $<180 \mu \mathrm{m}$ size fraction was selected as the fraction most likely to reflect element dispersion and mine site pollution. Rock samples were passed through a steel-jaw crusher, thoroughly mixed and a $100 \mathrm{~g}$ aliquot pulverised in a tungsten carbide steel ring mill.

Two vegetation species were collected, including saltbush (Atriplex spp.) and pepper tree (Schinus spp.). Four samples of vegetation were obtained: one of each species from near-background sites near the town site and one of each species from a fine crush rock dump south of the mill site (Figure $3 b$ ). Samples of live twigs and leaves of pepper tree and saltbush were obtained from plants growing on one of the large dumps of finely crushed material south of the mill site. The substrate material was several metres thick and had a typical total count scintillometer reading of $2100 \mathrm{cps}$. Samples of the same species were collected from sites on background soils (total count scintillometer of $\sim 125 \mathrm{cps}$ ) near the town. The vegetation samples were thoroughly washed and disaggregated, then ashed in an electric furnace at $600^{\circ} \mathrm{C}$ for $4-6 \mathrm{~h}$.

\section{Analytical methods}

Processed solid samples were analysed by instrumental neutron activation analysis (INAA) (Becquerel Laboratories, Sydney) for a range of major elements and trace elements (Ag, As, Au, Br, Ca, Ce, Cs, Co, Fe, Eu, Hf, Ir, K, La, Lu, Na, Rb, Sc, Se, Sm, Ta, Te, Th, U, W, Yb). Sample aliquots were also submitted to Australian Laboratory Services, Brisbane, where sample powders underwent fusion (lithium metaborate) and were analysed by inductively coupled plasma mass spectrometry (ICPMS) for $\mathrm{Ba}, \mathrm{Cu}, \mathrm{Mo}, \mathrm{Nb}, \mathrm{Pb}, \mathrm{Sn}, \mathrm{Ti}, \mathrm{V}, \mathrm{Y}, \mathrm{Zn}$ and $\mathrm{Zr}$. Paste $\mathrm{pH}$ measurements were performed on several powdered tailings and topsoils, following the procedure of Morin and Hutt (1997).

Polished thin-sections of waste rock samples were prepared and subsequently investigated for their mineralogy and petrography by optical microscopy. The mineralogy of selected waste rock, crushed rock, tailings, soil and stream sediment samples was identified using X-ray diffraction ( $\mathrm{Cu} \mathrm{K \alpha}$ : Siemens D5000 X-ray diffractometer) and computational software (SIROQUANT, EVA) at the Advanced Analytical Centre (AAC), James Cook University Townsville. Microprobe analyses were performed on brannerite, monazite and uraninite present in waste rock samples using a Jeol
JXA-8200 Superprobe also at AAC. The microprobe analyses are regarded as semi-quantitative because sample materials returned insufficient total element values compared with published mineral compositions obtained by microprobe analyses.

\section{RESULTS}

\section{Imagery}

The Radium Hill site is prominent on aerial photographs (Figure 4). Apart from obvious cultural remnants (e.g. roads, railway, building foundations, large concrete structures), the waste rock dumps, crushed rock dumps and tailings storage facilities are conspicuous. Uncovered waste rock and tailings materials have a grey colour with a blue tint, whereas soil coverings are pale orange-brown. The windborne dispersion plume of fine tailings about the main tailings storage facility is evident for several hundred metres distance (except to the southwest), causing a pale greyblue coloration of the soil.

Radiometric imagery of the region reflects bedrock geology and regolith, but the U channel also clearly demonstrates the effects of environmental dispersion (Figure 5). Diffuse U channel highs to the north, northeast and east-northeast of the mine and town sites are most likely due to outcropping bedrock. The mine area has an intense $U$ channel high, with the sharp anomaly that is subcircular and about $1.5 \mathrm{~km}$ in diameter. Away from the mine site, there is a diffuse weak $\mathrm{U}$ anomaly extending to the east and south for at least $0.7 \mathrm{~km}$, and this is interpreted to be in part due to the dispersion of windborne tailings. A slightly less intense $\mathrm{U}$ anomaly (with three high lobes) occurs over the town site. The gravelled road extending about $1.8 \mathrm{~km}$ east-northeast of the town and the asphalt road between the town and the mine form prominent $U$ anomalies. The former town site and main roads stand out due to the use of mine-derived crushed rock for construction.

On the Th channel, the immediate mine site also forms a prominent anomaly $<1 \mathrm{~km}$ in diameter (Figure 6). The town site is hardly discernible on this image, but bedrock and subcrop areas to the north, eastnortheast and immediately south of the mine form prominent diffuse anomalies. On the $\mathrm{K}$ channel, again the bedrock and subcrop regions form prominent diffuse highs, and the sandy (feldspathic) alluvium in Olary Creek draining southeast from the Radium Hill area forms a distinctive $\mathrm{K}$ channel anomaly. The mine area forms a sharp $\mathrm{K}$ channel anomaly about $1 \mathrm{~km}$ in diameter, probably due to K-bearing rocks being exposed by mining and incorporated into dumps, tailings and other forms of ground cover. A weak $\mathrm{K}$ channel anomaly is evident over the town.

\section{Waste rock dumps}

The waste rock dumps consist of broken rock material from the underground mine workings and are a thorough representation of the various rock types 

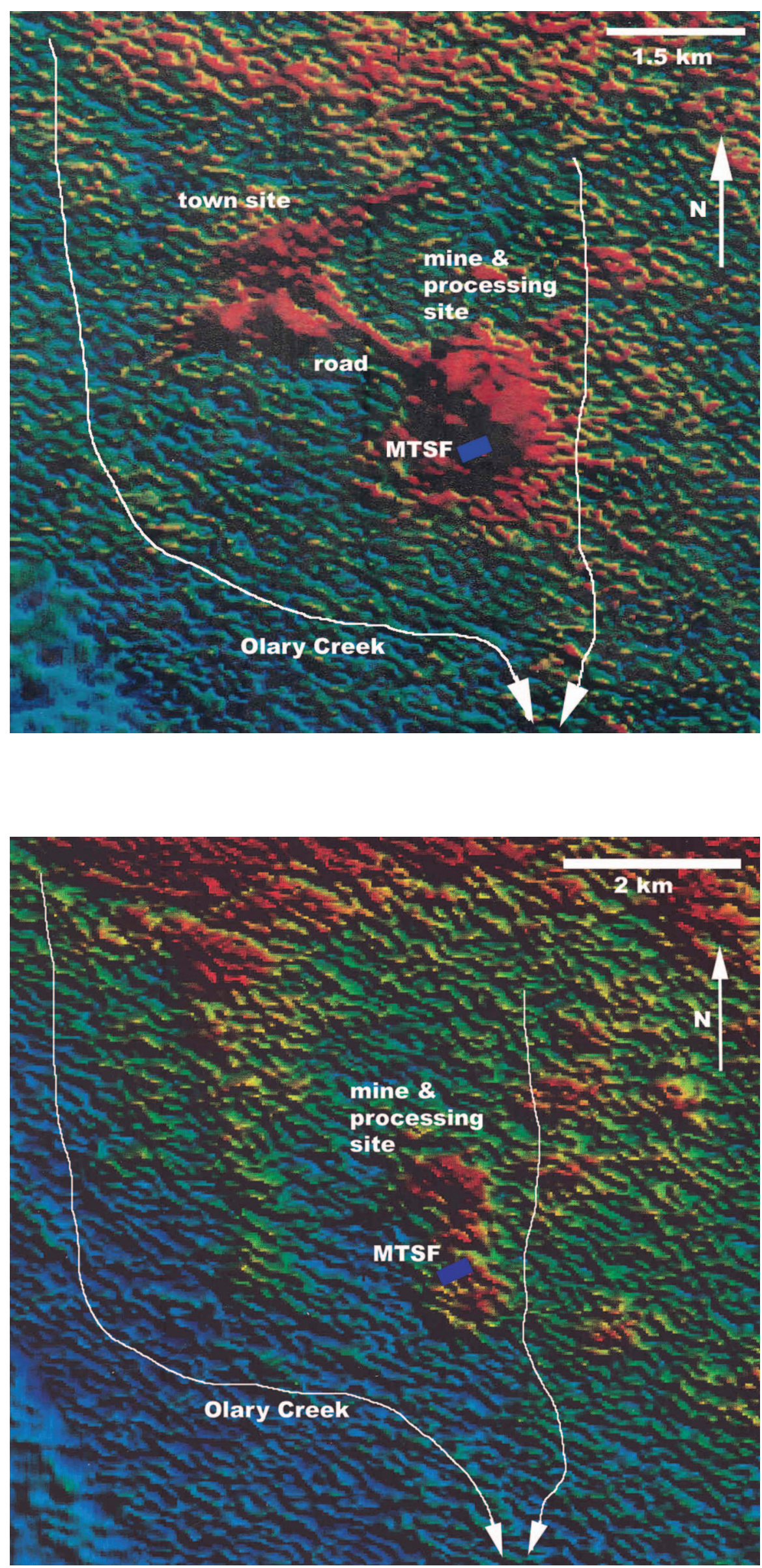

Figure 5 Radiometric image (uranium channel) of the Radium Hill site (courtesy of Primary Industries and Resources South Australia). The former town site and main roads stand out due to the use of mine-derived crushed rock for construction, and the mine area has a marked, complex $\mathrm{U}$ anomaly $\sim 1.5 \mathrm{~km}$ in diameter and a diffuse dispersion to the $\mathrm{E}$ and $S$ for a further $1-2 \mathrm{~km}$. The main tailings storage facility (MTSF) and local creeks are also shown.

Figure 6 Radiometric image (thorium channel) of the Radium Hill site (courtesy of Primary Industries and Resources South Australia). The mine area has a prominent Th anomaly $\sim 1 \mathrm{~km}$ in diameter. Bedrock and subcrop areas to the N, ENE and S of the mine site form diffuse anomalies. The main tailings storage facility (MTSF) and local creeks are also shown. 
encountered during mining. Particle size in the waste rock dumps varies from several tens of centimetres down to sandy material, and these dumps have remained relatively stable. Rock types include feldspar-quartz (-biotite) gneiss, locally grading into more micaceous and schistose types and biotite-rich altered types; amphibolite and its biotite-altered equivalents; pegmatite and various types of lode and shearzone rock material.

Lode material is commonly rich in coarse bluish quartz and black to bronze biotite, along with variable amounts of pink K-feldspar, albite, hornblende, rutile, ilmenite, hematite, chlorite, sericite, monazite, xenotime, allanite, apatite and traces of sulfides (pyrite, chalcopyrite, molybdenite). The uranium ore minerals brannerite and uraninite occur as minute grains $(0.01-$ $0.1 \mathrm{~mm}$ across) intergrown with oxide, REE mineral and sulfide phases, as evidenced by SEM studies. Evident ore-grade material $(0.1-0.2 \mathrm{wt} \% \mathrm{U})$ is characterised by aggregates of $\mathrm{Fe}-\mathrm{Ti}$ oxide minerals and high radiation levels (max. $5000 \mathrm{cps} ; 0.3-4.2 \mu \mathrm{Sv} / \mathrm{h}$ ). Waste rock samples display major $(>1 \mathrm{wt} \%$ ) median concentrations of $\mathrm{Fe}, \mathrm{K}$ and $\mathrm{Na}$, minor (>1000 ppm) $\mathrm{Ca}$ and $\mathrm{Ti}$, sub-minor $(>100 \mathrm{ppm}$ ) $\mathrm{Ba}, \mathrm{Ce}, \mathrm{Cr}, \mathrm{La}, \mathrm{Rb}, \mathrm{U}$ and $\mathrm{V}$, and traces $(<100 \mathrm{ppm})$ of As, Br, Co, Cs, Cu, Eu, Hf, Lu, Mo, Nb, Pb, $\mathrm{Sb}, \mathrm{Sc}, \mathrm{Sm}, \mathrm{Sn}, \mathrm{Ta}, \mathrm{Th}, \mathrm{Y}, \mathrm{Yb}, \mathrm{Zn}$ and $\mathrm{Zr}$ (Table 1). A correlation matrix of log-transformed geochemical data indicates high degrees of correlation $(r>+0.9)$ between ore elements $\mathrm{Ce}, \mathrm{Cr}, \mathrm{Sc}, \mathrm{La}, \mathrm{Lu}, \mathrm{Nb}, \mathrm{Ta}, \mathrm{Th}, \mathrm{Ti}$, $\mathrm{U}, \mathrm{V}, \mathrm{Y}$ and $\mathrm{Yb}$ in the waste rocks, reflecting the occurrence of an ilmenite-rutile-brannerite-uraninite-davidite-monazite-xenotime-apatite-allanite association. Electron microprobe analyses revealed Th-rich brannerite (up to $6.15 \mathrm{wt} \% \mathrm{ThO}_{2}$ ) and traces of uraninite as the dominant uranium ore minerals. Davidite was not detected in the collected samples.

\section{Crushed rock dumps and dispersed crushed rock}

Crushed rock material from the mine is found in several dumps in the mine and mill areas, and has been widely dispersed around the mine and town sites. Coarse crush material typically has a particle size of $2-10 \mathrm{~cm}$ and appears to have been screened. This material has been widely used as ground covering, gravel road surfacing and railway ballast, and for concrete. It typically has a total count scintillometer reading of $300-800 \mathrm{cps}$ and radiation levels of $0.2-$ $0.6 \mu \mathrm{Sv} / \mathrm{h}$. Fine crush material includes screenings ( $\sim 0.5-2 \mathrm{~cm}$ size), widely used for asphalt roads and concrete, and non-screened material that includes a high proportion of fines (sand- to silt-sized material). Dumps of the latter material have been subject to significant water and wind erosion (Figure $3 \mathrm{~b}$ ). Fine crush material is typically more radioactive than coarse crush and has total count scintillometer readings of $1000-2500 \mathrm{cps}$ and radiation levels of $0.7-$ $1.7 \mu \mathrm{Sv} / \mathrm{h}$. The composition of the crushed rock is likely to be an integration of all waste rock material, with abundant quartz, feldspars, biotite, plus local chlorite, sericite, amphibole and oxide minerals, including residual uranium minerals.
Crushed waste rock samples display relative elemental abundances largely identical to the waste rock samples (Table 1). They have major ( $>1 \mathrm{wt} \%$ ) median concentrations of $\mathrm{Fe}, \mathrm{K}$ and $\mathrm{Na}$, minor (>1000 ppm) $\mathrm{Ca}$ and Ti, sub-minor (>100 ppm) Ba, Ce, Cr, La, Rb, U, V, Y and $\mathrm{Zr}$, and traces ( $<100 \mathrm{ppm})$ of $\mathrm{As}, \mathrm{Br}, \mathrm{Co}, \mathrm{Cs}, \mathrm{Cu}, \mathrm{Eu}$, $\mathrm{Hf}, \mathrm{Lu}, \mathrm{Mo}, \mathrm{Nb}, \mathrm{Pb}, \mathrm{Sb}, \mathrm{Sc}, \mathrm{Sm}, \mathrm{Sn}, \mathrm{Ta}, \mathrm{Th}, \mathrm{Yb}$ and $\mathrm{Zn}$ (Table 1). Also, the analysis of log-transformed data indicates a high correlation between ore elements $\mathrm{Ce}$, Cr, Sc, La, Lu, Nb, Ta, Th, Ti, U, V, Y and $\mathrm{Yb}(r>+0.8)$ and $\mathrm{Pb}, \mathrm{Zn}, \mathrm{As}$ and $\mathrm{Sb}(r>+0.9)$, reflecting the occurrence of an ore mineral association and sulfide aggregates.

\section{Tailings}

The majority of mill tailings (probably >500 $000 \mathrm{t}$ ) are contained in the main tailings storage facility, with small volumes in two other identified dams. Exposed mill tailings in dams are commonly laminated (a consequence of wet sedimentation) and have a sandy to silty grainsize and texture. They are typically $<1 \mathrm{~mm}$ in grainsize and rich in quartz, feldspars and micas. Oxide minerals are also present, and residual uranium minerals evidently occur, as all tailings material is moderately to strongly radioactive, with typical total count scintillometer readings of $1400-$ $5500 \mathrm{cps}$ and high radiation levels (max. $3.5 \mu \mathrm{Sv} / \mathrm{h}$ ). Prior to capping, the tailings storage facilities were evidently prone to wind and water erosion, and gullying is still occurring on the sides of the dams (Figure 3c, d). Wind deflation of tailings before capping may have led to some preferential enrichment of mica in windblown material, as mica flakes would tend to be lifted and made airborne more readily than quartz and feldspars. Consequently, deposits of windblown tailings and topsoils about the main tailings storage facility are enriched in phyllosilicates (biotite, chlorite) as evidenced by XRD studies.

The tailings comprise variable amounts of primary gangue minerals (quartz, biotite, sericite, albite, chlorite, hornblende, K-feldspar). Paste $\mathrm{pH}$ measurements of the tailings indicate that the waste is non-acid producing with an average $\mathrm{pH}$ value of 9 . The materials display major $(>1 \mathrm{wt} \%$ ) median concentrations of $\mathrm{Fe}$, $\mathrm{K}$ and $\mathrm{Na}$, minor (>1000 ppm) $\mathrm{Ca}$ and $\mathrm{Ti}$, sub-minor $(>100 \mathrm{ppm}) \mathrm{Ba}, \mathrm{Ce}, \mathrm{Cr}, \mathrm{La}, \mathrm{Rb}, \mathrm{U}$ and $\mathrm{V}$, and traces $(<100 \mathrm{ppm})$ of As, Br, Co, Cs, Cu, Eu, Hf, Lu, Mo, Nb, $\mathrm{Pb}, \mathrm{Sb}, \mathrm{Sc}, \mathrm{Sm}, \mathrm{Sn}, \mathrm{Ta}, \mathrm{Th}, \mathrm{Y}, \mathrm{Yb}, \mathrm{Zn}$ and $\mathrm{Zr}$ (Table 1). Tailings have distinctly higher median $\mathrm{Cr}, \mathrm{Cu}, \mathrm{Rb}, \mathrm{Sc}$ and $\mathrm{V}$ concentrations than the waste rock dump and crushed waste rock materials (Table 1), reflecting a greater abundance of ore mineral aggregates and mica in the tailings. A correlation matrix of the logtransformed geochemical data indicates the highest degrees of correlation $(r>+0.9)$ for all sample types between $\mathrm{Fe}, \mathrm{Ti}, \mathrm{U}$, Th, Sc, Nb, Co, Pb, Y and REE (La, $\mathrm{Ce}, \mathrm{Sm}, \mathrm{Eu}, \mathrm{Yb}, \mathrm{Lu})$ in the tailings. This correlation probably reflects the residual coexistence of $\mathrm{Fe}-\mathrm{Ti}$ oxide (ilmenite-rutile), uranium mineral (brannerite, uraninite, davidite) and REE mineral (monazite, xenotime, apatite, allanite) assemblages in the analysed tailings. 


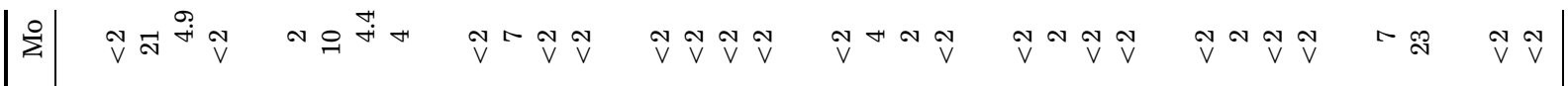

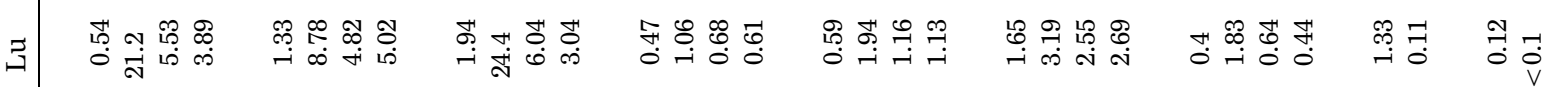

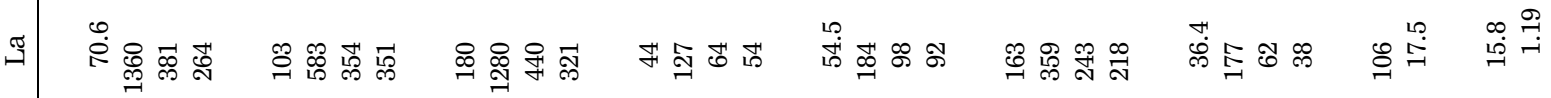

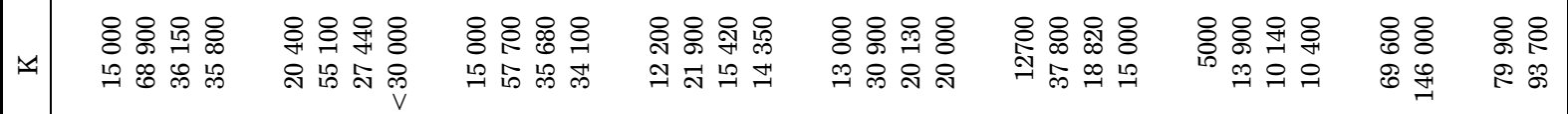

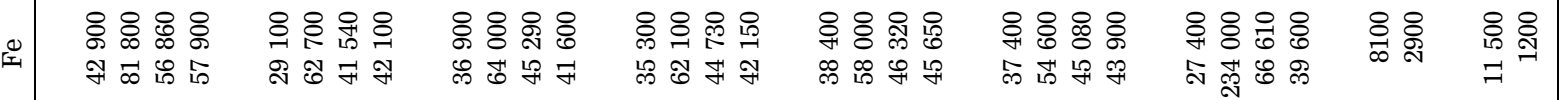

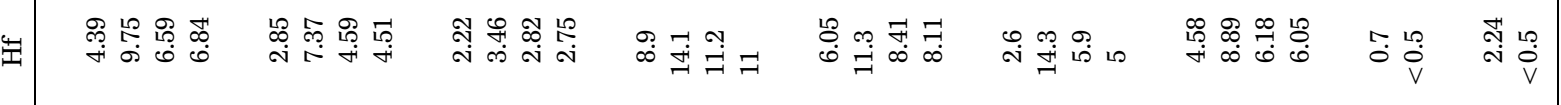

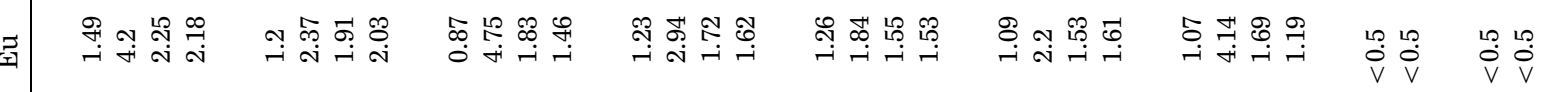
ఈ

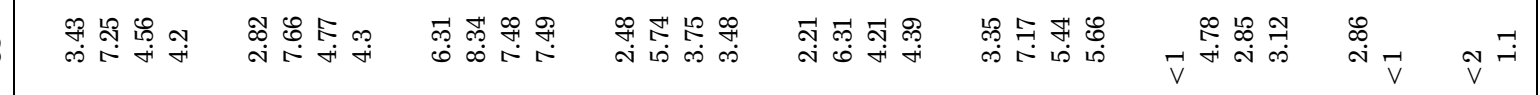

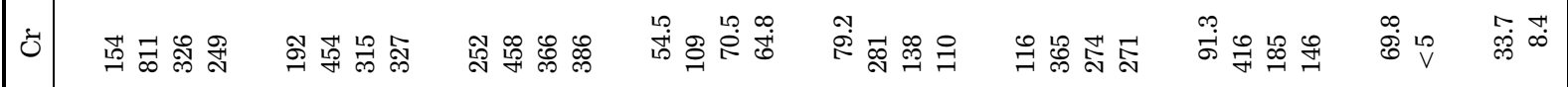

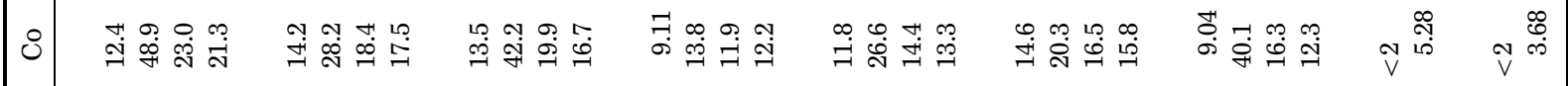
ல

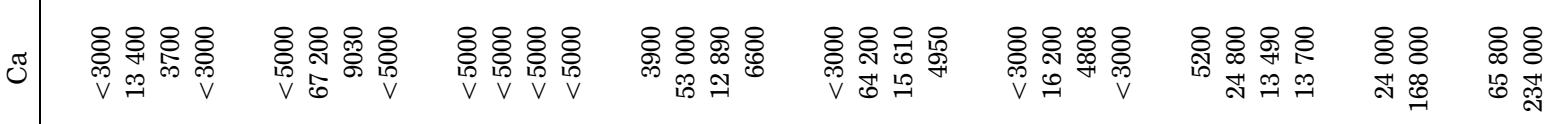

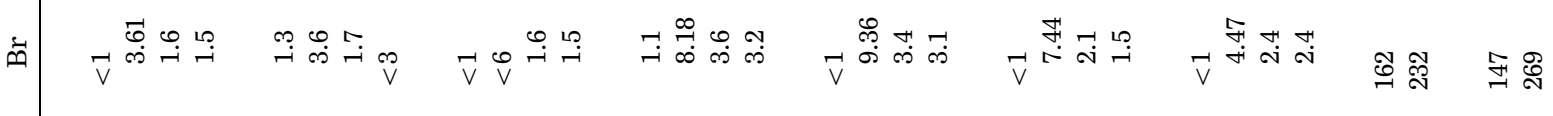

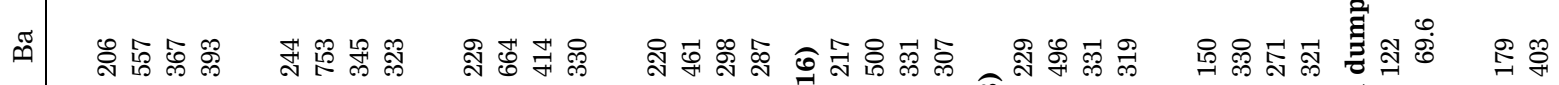

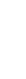

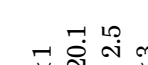
0 เ 
|ง|

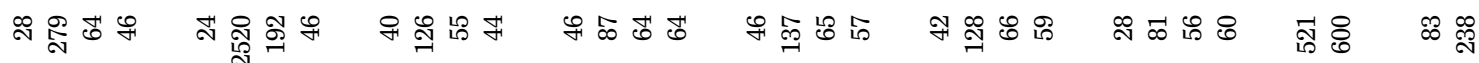

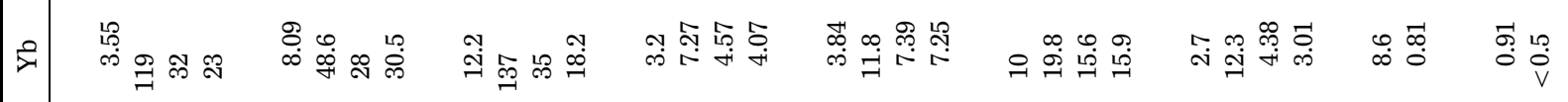

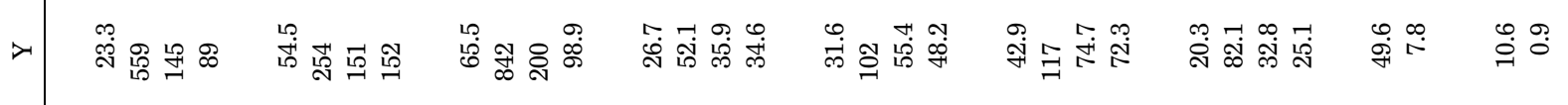

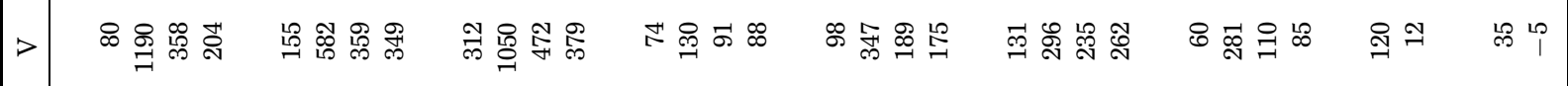

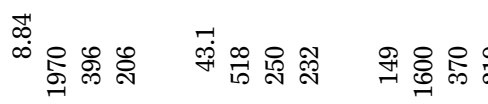

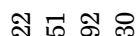

๓

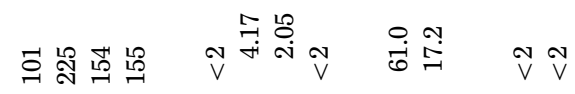

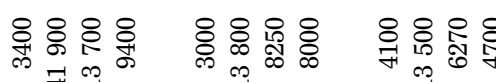

음 윰

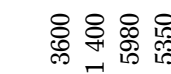

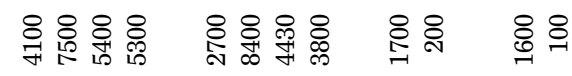

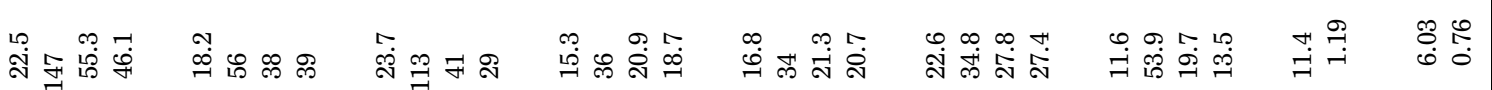

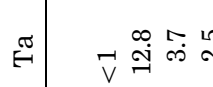

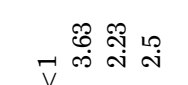

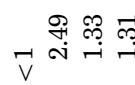

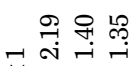

-

ㅊำ ศี

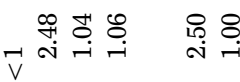

เุ 8

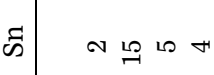

$-6 \stackrel{7}{7}$

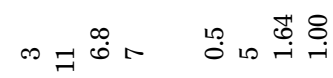

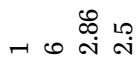

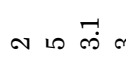

ง

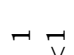

क्ष

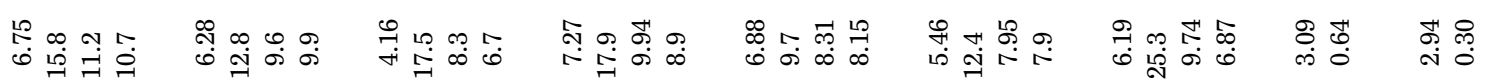

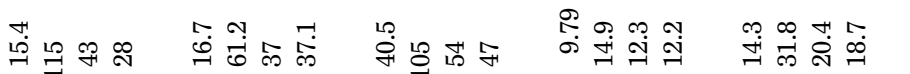

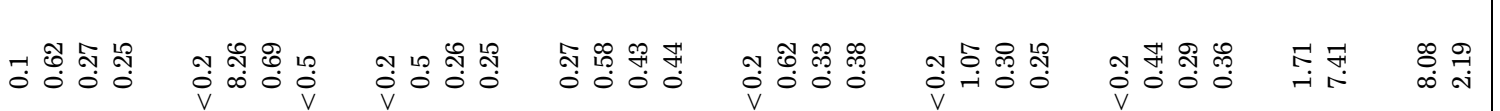

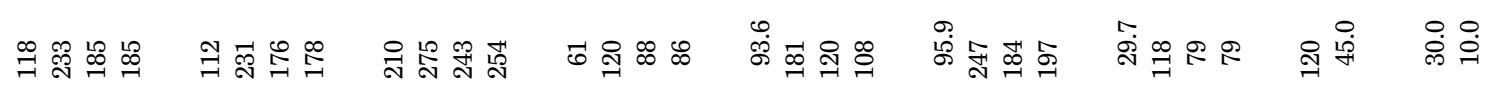

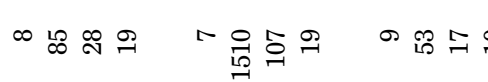

ㄱำ 总

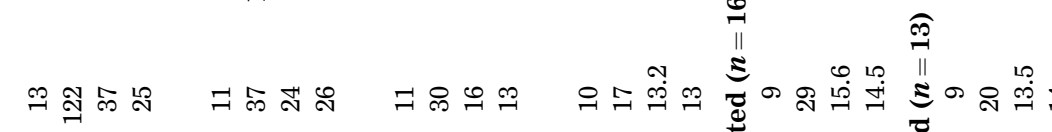
Eิ 8 \& 8 \&

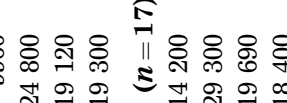

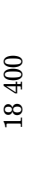

ช

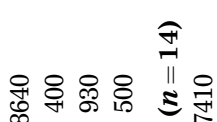

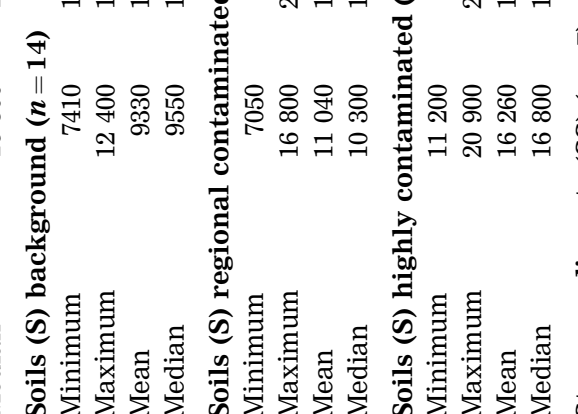

드

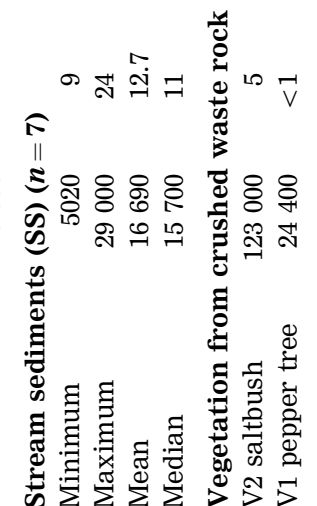




\section{Soils}

Background soil in the Radium Hill area is dominated by orange-brown (goethite-hematite-pigmented) silt-sand material, with abundant quartz, feldspar and clay minerals (largely kaolinite). In places, nodular calcrete is present at shallow depth in the soil profile. Such material has high paste $\mathrm{pH}$ values (mean $\mathrm{pH}$ 8.2), low total count scintillometer readings of $90-150 \mathrm{cps}$ and low radiation levels $(35-70 \mathrm{nSv} / \mathrm{h})$. Contamination of soil by mine-derived material includes admixing of crushed rock due to deliberate addition and dispersion by surface water flow. It also includes admixing and covering by windborne and waterborne mill tailings, resulting in soils adjacent to the main tailings storage facility having $>90 \mathrm{vol} \%$ of tailings material. Visibly contaminated soils display total count scintillometer readings of 180 $1500 \mathrm{cps}$ and elevated radiation levels (max. $0.94 \mu \mathrm{Sv} / \mathrm{h}$ ).

Residual soil over the subcrop zone of the line of lode in the mine area commonly contains detrital aggregates of oxide minerals up to $2-3 \mathrm{~cm}$ across, although uranium minerals are rare. Cappings of tailings storage facilities has involved the use of adjacent excavated soil, calcrete and weathered rock. It is possible that the sites of the excavations already had significant surficial contamination, but overall, the top surfaces of the capped tailings storage facilities have low to moderate total count scintillometer readings $(150-500 \mathrm{cps})$ and low radiation levels $(62-222 \mathrm{nSv} / \mathrm{h})$.

The ground radiometric survey revealed highly variable environmental $(\mathrm{nSv} / \mathrm{h})$ and assay data $(\mathrm{wt} \%$ $\mathrm{K}, \mathrm{ppm} \mathrm{U}$, ppm Th) of the soils southwest, southeast, east and northeast of the main tailings storage facility. Radiation levels range from 0.035 to $0.94 \mu \mathrm{Sv} / \mathrm{h}$. Elevated gamma-ray readings in the topsoils correspond to areas close to the main tailings storage facility (Figure 7a). Radiation levels gradually decrease with distance from the main tailings storage facility. Background radiation levels $(35-70 \mathrm{nSv} / \mathrm{h})$ and $\mathrm{U}$ contents $(0.4-2 \mathrm{ppm} \mathrm{U})$ are attained $\sim 400 \mathrm{~m}$ (southwest), $900 \mathrm{~m}$ (southeast), $700 \mathrm{~m}$ (east), and $>900 \mathrm{~m}$ (northeast) from the main tailings storage facility (Figure $7 \mathrm{a}, \mathrm{b}$ ).

Soils in the study area have been divided into three populations based on U content: background soils;

\section{(a)}

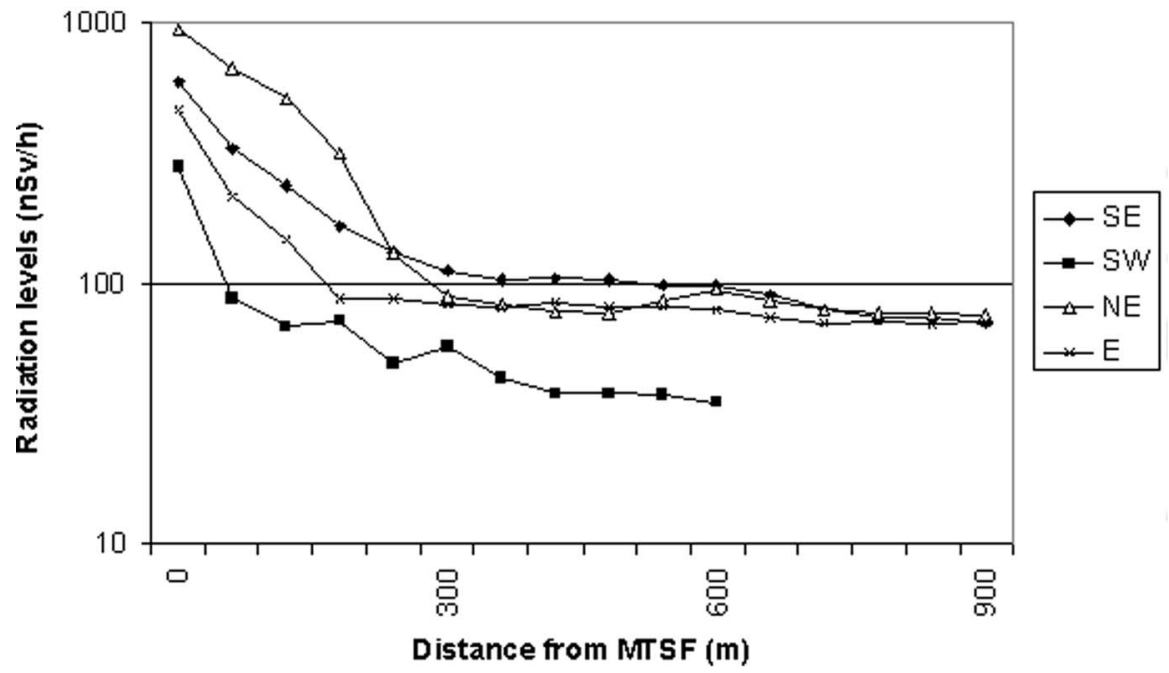

(b)

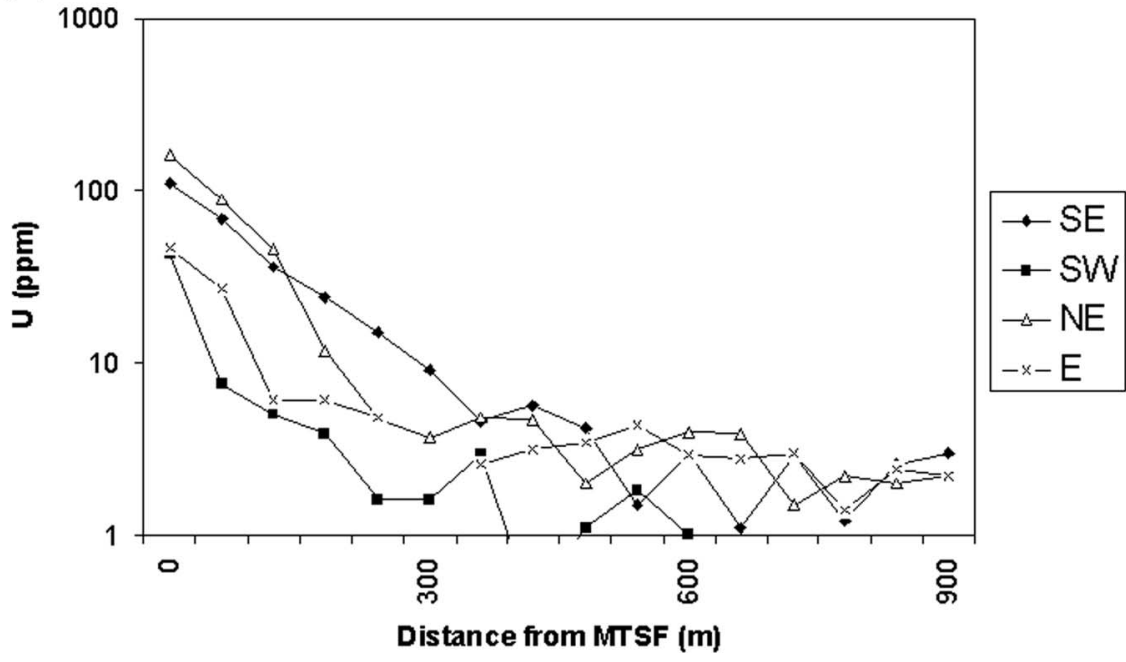

Figure 7 (a) Radiation level (nSv/h) and (b) U content (ppm) around the main tailings storage facility and adjacent soils. The data of the four ground radiometric survey transects (SE, SW, NE, E) are plotted so that the distance from the main tailings storage facility (MTSF) increases from left to right (60 $\mathrm{m}$ intervals). Locations of the survey transects are shown in Figure 2. 
regional contaminated soils; highly contaminated soils (Table 1). The highly contaminated population around the main tailings storage facility has $\mathrm{U}>100 \mathrm{ppm}$ and covers about $1 \mathrm{~km}^{2}$ (Figure 1). A regionally contaminated population is identified with $\mathrm{U}$ in the range $10-100 \mathrm{ppm}$. This contaminated area is conservatively estimated at $2 \mathrm{~km}^{2}$, mainly to the northwest and southeast of the main tailings storage facility (Figure 1). The elongated northwest-southeast dispersion pattern does not entirely conform to the airborne radiometrics (Figure 5) and probably reflects the low-density soil sampling conducted during this study. Soils with U $<10$ ppm have been defined as the background population. These samples were taken at distances of $\sim 0.5-8 \mathrm{~km}$ from the mine and processing site.

Background soils contain low concentrations of $U$ with the median $U$ value of $3.3 \mathrm{ppm}$, being consistent with established U concentrations in soils worldwide (Smith \& Huyck 1999). There is a strong correlation between $\mathrm{Fe}, \mathrm{Th}, \mathrm{Cr}$ and $\mathrm{REE}(>+0.9)$, indicating that these elements are largely held within Fe-oxyhydroxides. Such correlation may reflect the weathering of monazite and possibly oxide minerals, and subsequent incorporation of liberated REE into secondary Fe-rich phases in the soil profile.

Regional contaminated soils show marked increases in the median concentrations of $U(10 \times)$ as well as La, $\mathrm{Lu}, \mathrm{V}, \mathrm{Ce}, \mathrm{Cr}, \mathrm{Sc}, \mathrm{Y}$ and $\mathrm{Yb}(1.5-2 \times)$ compared with background soils (Table 1). Moderate correlation coefficients $(>+0.8)$ are present for $\mathrm{Na}, \mathrm{REE}, \mathrm{Cr}$ and $\mathrm{U}$, suggesting the presence of uranium (brannerite, uraninite, davidite) and REE (monazite, xenotime, apatite, allanite) minerals in the soils.

Highly contaminated soils at the mine and processing site and around the main tailings storage facility show extreme $U$ values (median $=155 \mathrm{ppm}$ ) as well as elevated median contents of Th $(1.5 \times), \mathrm{Rb}$ and $\mathrm{Y}(2 \times), \mathrm{Ce}, \mathrm{Sc}, \mathrm{V}$ and $\mathrm{Yb}(3 \times)$, and $\mathrm{Cr}$, La and $\mathrm{Lu}(4 \times)$ compared with background soils (Table 1 ). There is a strong correlation between $\mathrm{Cs}, \mathrm{Rb}$ and $\mathrm{Sc}(>+0.9)$ and, to a lesser degree, between $\mathrm{U}, \mathrm{La}$ and $\mathrm{Ce}(>+0.6)$, indicating that these soils contain admixtures of phyllosilicates as well as fine-grained ore mineral particles. Thus, the observed trace-element enrichment of topsoils appears to be largely due to the physical dispersion of tailings components from the waste repositories into the surrounding soils.

\section{Stream sediments}

In larger watercourses in the Radium Hill area, stream sediments are dominated by medium- to coarse-grained quartz-feldspar-lithic sand, grading to gravel. Smaller watercourses contain more silty stream sediments, due to a higher proportion of clays over detrital quartz and feldspar particles. Sandy beds locally contain concentrations of dark heavy minerals, evidently including ilmenite and magnetite, but no detrital uranium mineral concentrations were detected. All stream sediment sites sampled had near-background total count scintillometer readings of $80-125$ cps.

Stream sediment samples display major ( $>1 \mathrm{wt} \%$ ) median concentrations of $\mathrm{Fe}, \mathrm{Ca}, \mathrm{K}$ and $\mathrm{Na}$, minor
( $>1000 \mathrm{ppm}$ ) Ti, sub-minor (>100 ppm) Ba, Cr, and $\mathrm{Zr}$, and traces ( $<100 \mathrm{ppm}$ ) of $\mathrm{As}, \mathrm{Br}, \mathrm{Ce}, \mathrm{Co}, \mathrm{Cs}, \mathrm{Cu}, \mathrm{Eu}, \mathrm{Hf}$, $\mathrm{La}, \mathrm{Lu}, \mathrm{Mo}, \mathrm{Nb}, \mathrm{Pb}, \mathrm{Rb}, \mathrm{Sb}, \mathrm{Sc}, \mathrm{Sm}, \mathrm{Sn}, \mathrm{Ta}, \mathrm{Th}, \mathrm{U}, \mathrm{V}, \mathrm{Y}$, $\mathrm{Yb}$ and $\mathrm{Zn}$ (Table 1). Similarly to the background soils, there is a strong correlation between Fe, Ti, Th, Co, V, Y, $\mathrm{Cr}, \mathrm{Nb}$ and $\mathrm{REE}(>+0.9)$, indicating that these lithophile elements are largely held within Fe-oxyhydroxides and detrital oxide minerals. In addition, there is a strong correlation between $\mathrm{K}, \mathrm{Ba}, \mathrm{Rb}, \mathrm{Cs}, \mathrm{Pb}, \mathrm{Sc}$ and $\mathrm{Zr}$ $(>+0.9)$. Such correlations are thought to reflect the presence of alkali and alkali-earth elements in feldspars and zircon inclusions in micas.

\section{Vegetation}

Vegetation samples (V3, V4, Table 1) taken from background soil contain low lithophile (Cr, Rb, REE, Sc, Th, Ti, U, V, Y, Zr) element contents. At a crushed rock dump near the mill site where vegetation samples were taken, lithophile element values in substrates are higher, and the ashed plant samples clearly reflect the higher values (V1, V2, Table 1). A comparison between the same species growing on background versus contaminated sites shows that ashed material on contaminated sites commonly contains higher contents of lithophile elements. Pairs of plant samples (pepper tree Schinus spp., saltbush Atriplex spp.), growing on substrates with high contents of lithophile elements, show a distinct increase in the uptake of these elements (in ashed material) from contaminated substrates (Table 1). Ashed plant materials from the mill site contain significantly lower $\mathrm{Ca}$ and $\mathrm{Ba}$ values and higher values of lithophile and chalcophile elements (Mo, $\mathrm{Pb}, \mathrm{Zn}$ ) than those of ashed plant materials from the background site (Table 1). Moreover, saltbush growing on contaminated substrate displays distinctly higher $\mathrm{Na}$ (12.3 wt\%), Ti (0.17 wt\%) and lithophile element contents including $\mathrm{U}$ than the pepper tree.

\section{DISCUSSION}

\section{Primary contamination sources}

Contamination of soils by lithophile elements at the Radium Hill mine and processing site is due to two main sources: (i) the use of crushed waste rocks as a ground cover (e.g. around many buildings) and for roads; and (ii) the erosion of steep waste rock dumps and tailings repositories and physical dispersion of mine waste particles into local soils. In particular, the waste rock dumps and tailings storage facilities have acted as point sources of contamination and have affected the immediate area. At the mine and processing site, the significant correlation of $\mathrm{Cs}, \mathrm{Rb}$ and $\mathrm{Sc}(>+0.9)$ and, to a lesser degree, between $\mathrm{U}$, La and $\mathrm{Ce}(>+0.6)$ in the highly contaminated soils highlight the physical dispersion of fine-grained tailings from the main tailings storage facility into local soils. This transfer of contaminants from the main tailings storage facility into soils largely occurred prior to capping of the main tailings storage facility in the 1980s. Currently, wind and water erosion of tailings repositories and crushed waste rock dumps remains active at covered and uncovered sites (Figure 3c, d). 
It is important to note that the waste rock materials and tailings are essentially free of sulfide minerals. It is estimated that sulfides constitute $<0.1 \%$ by volume of these materials. With the prevailing low rainfall and high evaporation rates, infiltration of rain and surface waters into the dumps is probably low, with leaching reactions and seepages of leachate solutions being minimal. Sparsely disseminated fresh pyrite occurs on waste rock dumps and has essentially remained unoxidised after several decades' exposure to the atmosphere.

\section{Dispersion into soils and vegetation}

Windblown tailings material up to tens of centimetres thick is common up to $80 \mathrm{~m}$ away on the northeast and southeast sides of the main tailings storage facility, but thinner further away and on the northwest and southwest sides. Small amounts of windblown tailings remain evident for at least $500 \mathrm{~m}$ distant on the southeast side of the main tailings storage facility (Figure 4). The dispersion to the northeast and southeast reflects the direction of the prevailing strong winds, although east of the main tailings storage facility, the dispersion plume has probably been largely removed by subsequent flooding of a wide stream channel (Figure 2). Contaminated soils at the mine and processing site have acquired their trace-element contents from the windborne and waterborne erosion of fine-grained ore particles and their subsequent dispersion into local soils. Currently, contaminants are not dispersed into stream channels because the geochemical composition of stream sediments downstream of the mine and processing site does not exceed background values.

The correlation matrices of log-normalised data of background soils and stream sediments reveal nonsignificant correlation coefficients between $U$ and most other elements. Thus, in background soils and stream sediments, $\mathrm{U}$ is probably adsorbed on to mineral grains. Sorption plays an important role in determining the fate of $U$ in the aquatic and soil environment (Elless \& Lee 1998). Radium Hill tailings display strong correlations of $\mathrm{U}$ with lithophile elements, reflecting the presence of primary uranium ore mineral aggregates. Also, the regional contaminated and highly contaminated soils still display significant, yet slightly diminished correlations of $U$ with other lithophile elements. Therefore, breakdown of windborne and waterborne uranium ore minerals, through the actions of oxygen, water and catalytic bacteria, is limited in the $U$ contaminated topsoils. Yet, during rare rainfall events, the leaching of $\mathrm{U}$ in uncapped waste rock dumps and contaminated soils is likely to occur. Oxidation and leaching of the uranium ore minerals would lead to the limited liberation of trace elements from their host minerals. Lithophile (e.g. Cr, Rb, REE, Sc, Th, Ti, U, V) and chalcophile elements (e.g. Mo, $\mathrm{Pb}, \mathrm{Zn}$ ) would slowly dissolve during rainfall events, with these elements being chemically mobilised into soils, thus becoming bioavailable to vegetation.

The biogeochemical data clearly show that significant bioaccumulation of lithophile elements occurs in plants growing in the disturbed sites. In particular, the
LREE contents of ashed saltbush from the crushed waste rock dumps are highly anomalous and well above $(100 \times)$ published values for LREE contents in plants growing on contaminated soils (Pfeifer et al. 1994). In addition, there is significant enrichment of $U$ in saltbush (V2, Table 1).

The major land use of the rehabilitated Radium Hill site is low-density grazing, and a consequence of $\mathrm{U}$ uptake into vegetation is that there is the potential to transfer toxicants into grazing animals. A risk assessment is required to determine the potential impact of $U$ enriched topsoils and vegetation on grazing animals. However, the uptake of $U$ into plants is probably restricted in area to no more than $1 \mathrm{~km}^{2}$.

\section{Rehabilitation}

The mean exposure rate calculated from 38 individual geophysical traverses from the mine and processing site amounts to $0.67 \mu \mathrm{Sv} / \mathrm{h}$. Australian Radiation Protection Standards (ARPANSA 1995) limit the exposure to ionising radiation, and the dose limit for the public has been set at $1 \mathrm{mSv} /$ year. Also, radiation levels from most sample media are not significant, bearing in mind the remote location and good ventilation. Thus, visitors to the Radium Hill site will not be exposed to excessive radiation levels. However, exposure of mill tailings by future erosion could become a more substantial issue as tailings generally have the highest radiation dose. The current covered tailings storage facilities do not have long-term geomorphic stability and are already subject to rill erosion, and in the future might be subject again to significant wind erosion. A long-term management strategy must require capping of waste dumps and reconfiguration of the main tailings dam to a stable landform.

\section{CONCLUSIONS}

The Radium Hill uranium mine in South Australia ceased operations in 1961 and underwent rehabilitation in the 1980s. The mine area now consists of numerous waste rock dumps, several tailings storage facilities and numerous relicts and foundations of buildings and other structures. The waste dumps are prone to physical erosion involving wind and seasonal rain. Physical dispersion of mineralised particles from waste rock dumps and tailings repositories, has led to local enrichment of lithophile elements (Ce, Cr, La, Lu, Rb, Sc, Th, U, V, Y, Yb) in adjacent soils. Plants (pepper tree, saltbush), growing on contaminated soil, display enhanced uptake of lithophile elements. The enrichment in common species implies that there is potential for transfer of $U$ into grazing animals and their bioaccumulation. Additional capping and landform design of the crushed waste and tailings repositories are required in order to minimise erosion and impacts on surrounding soils and sediments.

\section{ACKNOWLEDGEMENTS}

The study was supported by the Australasian Institute of Mining and Metallurgy Gold 88 Endowment Fund and 
Australian Institute of Nuclear Science and Engineering (grant no. 03/075). Alistair Crooks (Primary Industries and Resources South Australia) is thanked for provision of geophysical data and orientation at the field site. R. Watkins and B. Dickson are thanked for their reviews of the manuscript.

\section{REFERENCES}

Abdelouas A., LuTze W. \& NutAll E. 1998. Chemical reactions of uranium in ground water at a mill tailings site. Journal of Contaminant Hydrology 34, 343-361.

ARPANSA (AUSTRALIAN RADIATION PROTECTION AND NuCleAR SAFETY AGENCY) 1995. Recommendations for limiting exposure to ionizing radiation. Radiation Protection Series Publication 1.

Blissett A. H. 1975. Willyama Mount Painter and Denison Inliers. Sundry mineralisation in South Australia. In: Knight C. L. ed. Economic Geology of Australia and Papua New Guinea 1. Metals, pp. 498-505. Australasian Institute of Mining and Metallurgy Monograph 5.

BuREAU OF MEtEOROLOGY 2005. Wind roses for selected locations in Australia. Online <http://www.bom.gov.au/climate/averages/ wind/selection_map.shtml>

Conor C. H. H. 2000. Definition of major sedimentary and igneous units of the Olary Domain, Curnamona Province. MESA Journal 19, $51-56$.

ELLESS M. P. \& LEE S. Y. 1998. Uranium solubility of carbonate-rich uranium-contaminated soils. Water, Air, \& Soil Pollution 107, $147-162$.

FORBES B. J. 1991. Olary, South Australia, Sheet SI 54-2, 1:250000 Series Explanatory Notes. Geological Survey of South Australia, Adelaide.

LOTTERMOSER B. G. 2003. Mine Wastes: Characterization, Treatment and Environmental Impacts. Springer, Berlin.

LOTTERMOSER B. G. \& Ashley P. M. 2005. Tailings dam seepage at the rehabilitated Mary Kathleen uranium mine, Australia. Journal of Geochemical Exploration 85, 119-137.

MAWSON D. 1906. On certain new mineral species associated with carnotite in the radioactive ore body near Olary. Transactions of the Royal Society of South Australia 30, 191.

McKAY A. D. \& MiEZITIS Y. 2001. Australia's uranium resources, geology and development of deposits. Geoscience Australia Mineral Resource Report 1.
MEnZies N. W. \& Mulligan D. R. 2000. Vegetation dieback on claycapped pyritic mine wastes. Journal of Environmental Quality 29, 437-442.

MoRIN K. A. \& HUTT N. M. 1997. Environmental Geochemistry of Minesite Drainage. MDAG Publishing, Vancouver.

PARKIN L. W. 1965. Radium Hill uranium mine. In: McAndrew J. ed. Geology of Australian Ore Deposits: Proceedings of the 8th Commonwealth Mining and Metallurgical Congress, vol. 1, pp. 312-313. Australasian Institute of Mining \& Metallurgy, Melbourne.

PARKIN L. W. \& GLASSON K. R. 1954. The geology of the Radium Hill uranium mine, South Australia. Economic Geology 49, 815-825.

Peacey V., Yanful E. K. \& Payne R. 2002. Field study of geochemistry and solute fluxes in flooded uranium mine tailings. Canadian Geotechnical Journal 39, 357-376.

Pfeifer H. R., Vust M., Meissner N., DopPenberg R., Torti R. C., Domergue F. L., Keller C. \& HunziKer J. 1994. Uraniumenrichment in soils and plants in the vicinity of a pitchblende vein at La Creusaz/Les Marecottes (W of Martigny, Valais, Switzerland). Eclogae Geologicae Helvetiae 87, 491-501.

Richards R. J., Applegate R. J. \& Ritchie A. I. M. 1996. The Rum Jungle rehabilitation project. In: Mulligan D. ed. Environmental Management in the Australian Minerals and Energy Industries, pp. 530-553. University of New South Wales Press, Sydney.

Ritchie A. I. M. \& BennetT J. W. 2003. The Rum Jungle mine-a case study. In: Jambor J. L., Blowes D. W. \& Ritchie A. I. M. eds. Environmental Aspects of Mine Wastes, pp. 385-405. Mineralogical Association of Canada, Ottawa.

SMiTH K. S. \& HUYCK H. L. O. 1999. An overview of the abundance, relative mobility, bioavailability, and human toxicity of metals. In: Plumlee G. S. \& Logsdon M. J. eds. The Environmental Geochemistry of Mineral Deposits. Part A: Processes, Techniques and Health Issues, pp. 29-70. Reviews in Economic Geology 6A.

TAylor G., Spain A., Timms G., Kuznetzov V. \& BennetT J. 2003. The medium-term performance of waste rock covers-Rum Jungle as a case study. In: Farrell T. \& Taylor G. eds. 6th International Conference on Acid Rock Drainage, pp. 383-397. Australasian Institute of Mining and Metallurgy, Melbourne.

VAN LoON J. C. \& BAREFoOt R. R. 1989. Analytical Methods for Geochemical Exploration. Academic Press, San Diego.

WhitTLE A. H. G. 1959. The nature of davidite. Economic Geology $\mathbf{5 4}$, $64-81$.

Received 13 July 2005; accepted 8 December 2005 
